\title{
„Księga wspólnoty” czy „wspólnota księgi”? Problem lokalizacji autorytetu teologicznego
}

W artykule Jonathana R. Wilsona pt. Canon and Theology: What Is at Stake? zawartym w jednym z ostatnich opracowań dotyczących pochodzenia Biblii znajdziemy równie interesujące, co prowokujące stwierdzenie:

Tak więc w okresie rozwiniętego modernizmu widzimy nowy rodzaj relacji pomiędzy kanonem, kanonicznością i teologią. W tradycji protestanckiej kanon został wyniesiony ponad historię, a praca teologiczna jest nieograniczona czasem. W tradycji katolickiej Kościół jest wyniesiony ponad historię, a praca teologiczna jest nieograniczona czasem. W modernizmie, kanon i Kościół są widziane w perspektywie historycznej, a ludzkość jest wyniesiona ponad historię albo poprzez odniesienie do „koniecznych prawd rozumu”, albo do uniwersalnego doświadczenia religijnego¹.

W powyższym stwierdzeniu niejeden zauważyć może pewne uproszczenie, niemniej samo rozłożenie akcentów w podejściu do tematu Pisma Świętego i wspólnoty kościelnej wydaje się zgodne z tym, o czym wiemy z historii danych części chrześcijaństwa. Różnica konfesyjna w omawianym temacie jest dobrze znana: protestancki postulat absolutyzujący Biblię czy katolickie zdecydowane podkreślenie autorytetu Kościoła? W obecnym artykule proponuje się przyjrzeć tym z ważniejszych wyników współczesnych nauk biblijnych, które mogą pomóc w jak najlepszym

${ }^{1}$ Tłumaczenie własne tekstu: „In high Modernity, then, we see a new turn in the relationship between the canon, canonicity, and theology. In the Protestant tradition, the canon is dehistoricized and the work of theology is timeless. In the Catholic tradition, the church is dehistoricized and the work of theology is timeless. In Modernity, the canon and the church are historicized and humankind is dehistoricized, either by an appeal to "the necessary truths of reason" or to universal religious experience" (J. R. Wilson, Canon and Theology: What Is at Stake?, [w:] Exploring the Origins of the Bible. Canon Formation in Historical, Literary, and Theological Perspective, Grand Rapids 2008, s. 247). 
ustawieniu relacji Pisma Świętego do wspólnoty wiary w perspektywie historyczno-teologicznej. Od prawidłowości tej relacji zależy zarówno sam proces interpretacji tekstu biblijnego, jak i aktualny dziś temat umiejscowienia autorytetu teologicznego.

\section{Biblia w procesie formacji pism}

Pierwszych znaczących cech charakteryzujących relację pomiędzy pismami a wspólnotą wiary doszukiwać się możemy już na etapie tworzenia się poszczególnych pism. Zwróćmy najpierw uwagę na rolę wspólnoty wiary.

Jak wykazuje J. A. Sanders², twórca krytyki kanonicznej, czyli podejścia biblijnego, który poświęcił większość swoich prac badaniom historii formowania się Biblii, w procesie kanonicznym rola wspólnoty wiary była pierwszoplanowa. To w tej wspólnocie (najpierw Izraela, a później młodego Kościoła) dokonywano wyboru, a następnie aktywnego przekazywania wybranych tradycji i tekstów. Mówi się tu o "aktywnym" przekazie, ponieważ był to często proces kreatywny, nie tylko przekazujący dane słowa i wydarzenia, ale próbujący często aktualizować je w nowych okolicznościach, w których lud Boży musiał bronić swej wiary i tożsamości. W procesie tym na przykład słowa wielkich proroków odległych wieków mogły nie tylko zachować swój autorytet i aktualność, ale również odnaleźć nowe znaczenie oparte na treściowym bogactwie tekstów i tradycji, a wydobyte w nowych kontekstach historycznych i literackich. W ten sposób rozrastały się stopniowo poszczególne tradycje i teksty aż po formę danych ksiąg biblijnych.

Cały ten proces odbywał się we wspólnocie, będąc niejako zanurzonym w jej wierze i tradycji. Rola wspólnoty wiary jest więc tu oczywista. To w jej ramach odbywało się formowanie, przekaz i relektura, które napędzały cały proces formowania się pism. W tym znaczeniu wspólnota kształtowała pisma, choć człowiek wiary rozpo-

${ }^{2}$ Jasne przedstawienie wyników badań Sandersa znaleźć można w jego krótkim (78 stron) Canon and Community. A Guide to Canonical Criticism, Philadelphia 1984. Do innych jego ważniejszych pozycji należą: Torah and Canon, Philadelphia 1972; From Sacred Story to Sacred Text. Canon as Paradigm, Philadelphia 1987; Early Christian Interpretation of the Scriptures of Israel. Investigations and Proposals, Sheffield 1997; The Canon Debate, Peabody 2002. 
zna z łatwością, że w tej wspólnocie działał nie kto inny, jak sam Bóg. W procesie tym, jak zauważa Sanders, do głosu dochodziły wciąż dwie ważne cechy tekstów i tradycji, które mogły aspirować do stania się ostatecznie częścią Biblii. Jedną z nich była stabilność, a drugą zdolność do bycia adaptowanym. To dzięki owej stabilności dane tradycje były ciągłym punktem odniesienia dla kolejnych pokoleń danej wspólnoty. Otwarcie na adaptację uzdalniało natomiast te tradycje do reinterpretacji i aktualizacji we wciąż nowych sytuacjach, owocując rozwojem całości pism i objawienia.

J. A. Sanders zauważa też kluczową rolę wspólnoty w sposobie interpretowania tekstów i tradycji wchodzącym w skład tzw. hermeneutyki kanonicznej. W ramach tej ostatniej, wszelki materiał docierający do autorów biblijnych był przez nich opracowywany w zgodzie z tradycją wiary, swoistym credo wspólnoty 3 . To po raz kolejny opinia wspólnoty jest tu zauważona jako dominująca w określeniu kształtu pism.

Wszystko to zdaje się sugerować, że w relacji wspólnota-pismo w historii formacji biblijnej to wspólnota jest dominująca. To ona w formie i treści zdaje się określać Pismo. Czy tak jest rzeczywiście? Spróbujmy teraz spojrzeć na omawianą kwestię ze strony ewentualnego oddziaływania pism na wspólnotę.

To prawda, że pisma formowane były w łonie ludu Bożego. Nie możemy jednak zapominać, że lud ów odczuwał potrzebę otrzymania wiedzy i praktycznego pouczenia w swym działaniu i poszukiwał ich w autorytecie samego Boga. Konkretnym odniesieniem były natomiast autorytatywne tradycje i pisma, które były nośnikami relacji dotyczących Bożych interwencji w historii, Prawa czy przekazów prorockich. To w ich świetle lud Boży się kształtował, to one pozwalały rozwijać się strukturom religijnym i społecznym narodu, jak również wzrastać w Bożej mądrości poszczególnym jego członkom. Dzięki swemu walorowi teologicznemu poszczególne teksty i tradycje mogły być obiektem i natchnieniem do refleksji dla kolejno przychodzących pokoleń, pomagając we właściwym

\footnotetext{
${ }^{3}$ Wiarę czasów starotestamentalnych Sanders opisuje słowami: „monoteizujący pluralizm". Chodzi tu o dążenie hagiografów do wierności zasadzie monoteizmu z zachowaniem jednak wielości form i ujęć typowych dla danych źródeł i wspólnotowych tradycji. Stąd w Biblii bogactwo odcieni literackich, a nawet różnych ujęć teologicznych z dominującą jednak i wszystko ogarniającą troską o zachowanie czystości wiary w jedynego Boga.
} 
odczytaniu oraz interpretacji poszczególnych etapów dziejów wspólnoty wiary. W takim znaczeniu to pisma kształtowały wspólnotę.

Już na etapie powstawania pism biblijnych zauważyć można wzajemne oddziaływanie pomiędzy nimi samymi a wspólnotą ludu Bożego. To prawda, że pisma są formowane przez członków wspólnoty wiary, ale jednocześnie to w ich świetle ta wspólnota się kształtuje. W następnym punkcie przyjrzyjmy się temu, w jakim wymiarze ten egzystencjalny i jednocześnie teologiczny dialog był kontynuowany na etapie formowania się poszczególnych ksiąg w zbiór kanonu biblijnego.

\section{Biblia w procesie formacji kanonu}

Powstanie poszczególnych zbiorów ksiąg (Prawa, Proroków, Pism w Starym Testamencie czy też Ewangelii i Listów św. Pawła w Nowym Testamencie), a później powstanie kanonu całej Biblii chrześcijańskiej nie jest zrozumiałe bez przyjęcia aktywnej roli wspólnoty ludu Bożego. To w ramach tej wspólnoty musiał się dokonać ostateczny wybór pism autorytatywnych, które miały wejść w skład kanonu.

Najlepszym przykładem jest tu historia pierwszych wieków chrześcijaństwa z rozwijającym się wtedy dynamicznie procesem formacji kanonu biblijnego. W ramach wspólnoty musiało dojść do aktywnego rozpoznania tych wyjątkowych, obdarzonych boskim autorytetem kanonicznych ksiąg. Kościół nie wypracował w tym czasie formalnego elenchusa kryteriów, które pozwalałyby na pewne rozpoznanie danych ksiąg. Niemniej w praktyce stosował ich wiele bez zbytniej troski o formalną systematykę ich użycia. H. Gamble zauważa na przykład:

Winno być jasnym, że kryteria kanoniczności we wczesnym Kościele były liczne, różne i zdefiniowane ogólnie, że ich zastosowanie nie było systematyczne i do końca konsekwentne oraz że były używane w przeróżnych kombinacjach ${ }^{4}$.

Mimo że nie było dopracowanego systemu kryteriów, kryteria jako takie funkcjonowały i były jasnym znakiem działalności wspólnoty wiary. Ich obecność uwidacznia się w pismach ojców Kościoła i pisarzy

${ }^{4}$ Tłumaczenie własne tekstu: „It should be clear that the principles of canonicity in the early church were numerous, diverse, and broadly defined, that their application was not systematic or thoroughly consistent, and that they were used in variety of combinations" (H. Gamble, The New Testament Canon: its making and meaning, Philadephia 1985, s. 71). 
starożytności chrześcijańskiej takich jak Ireneusz, Tertulian, Orygenes czy Augustyn. Najważniejszymi wyznacznikami ksiąg kanonicznych były dla nich starożytność i autentyczność danej księgi, powszechne użycie w prawowiernym kościelnym środowisku oraz ortodoksja 5 . Autentyczność księgi zakładała, że pochodzi ona od apostoła lub z kręgu jego najbliższych współpracowników ${ }^{6}$. W przypadku ksiąg starotestamentalnych zasada ta wyrażała się w uznaniu, jakim cieszyły się te księgi w środowisku apostolskim. Ortodoksja funkcjonowała przede wszystkim na poziomie lektury tekstu w kontekście żywej Tradycji Kościoła, w kórej uznawano przekazywaną od czasów apostolskich regułę wiary - istotne credo chrześcijańskie ${ }^{7}$. Pismo aspirujące do kanonu nie mogło stać w opozycji doktrynalnej wobec owej reguły, jeżeli samo miało być w Kościele wykładnią owego credo. Rola wiary wspólnoty jako czynnika formującego Biblię jest tu ewidentna. Poza tym, zasada ortodoksyjności mogła przyjmować charakter bardziej wewnętrzny dla samej Biblii.Jako że niektóre pisma (w Nowym Testamencie na przykład Ewangelie i Listy Pawłowe) formowały się szybciej w określone zbiory niż inne księgi, te, których autorytatywną wartość z czasem powszechnie już rozpoznano, nie mogły stawać w doktrynalnej sprzeczności z przyjętymi uprzednio.

Według K. H. Ohliga ${ }^{8}$ kryteria wymienione powyżej należą do tzw. kryteriów zewnętrznych. Obok już wspomnianych autor ten wymienia również w tej grupie inne, takie jak to, że dane pismo nadawało się do lektury publicznej, a nie tylko prywatnej oraz że uwidaczniała się w nim teologiczna użyteczność dla większej ilości Kościołów lokalnych. Także inna cecha - charakter instrukcyjny danego pisma budujący wiarę wspólnoty - mogła stać się jednym z wyznaczników kanoniczności. „Kryteria zewnętrzne” kanoniczności dotyczą cech samych pism. Niemniej cechy te były rozpoznawane nie gdzie indziej, jak we wspólnocie wiary. To ona była ich destynatariuszem $i$ to $w$ jej łonie dokonywał

${ }^{5}$ Por. M. Ludlow, „Criteria of canonicity” and the Early Church, [w:] Die Einheit der Schrift und die Vielfalt des Kanons, hrsg. von J. Barton, M. Wolter, Berlin-New York 2003, s. 73.

${ }^{6}$ Por. Tertulian, Adversus Marcionem, IV, 2; Ireneusz, Adversus Haereses, III, 10, 5; III, 14, 1.

${ }^{7}$ Por. Tertulian, De praescriptione haereticorum, XIX; Ireneusz, Adversus Haereses, II, 27, 2.

${ }^{8}$ Por. K. H. Ohlig, Wohernimmt die Bibel ihre Autorität? Zum Verhältnis von Schriftkanon, Kirche und Jesus, Düsseldorf 1970; Die theologische Begründung des ntl. Kanons in der Alten Kirche, Düsseldorf 1972. 
się proces ich „oceny” i selekcji. W temacie formowania się Biblii rola wspólnoty znowu wychodzi więc na pierwszy plan. Staje się to jeszcze bardziej wyraźne, gdy weźmiemy pod uwagę inną grupę kryteriów zwanych przez Ohliga „kryteriami kościelnymi”.

Kryteria te są dla nas szczególnie interesujące, bo dotyczą bezpośrednio praktyki Kościoła. Nie chodzi w nich wprost o same pisma, lecz raczej o relację wspólnoty wiary do owych pism oraz do kryteriów wcześniej wspominanych. Krótki katalog tych kryteriów powinien dać tego wyjaśniające zobrazowanie.

Do tej grupy wyznaczników kanoniczności zalicza się m.in. rozpoznanie danej księgi przez jak największą liczbę Kościołów lokalnych. Księgi były oczywiście rozpoznawane w oparciu o te cechy pism, które były przedmiotem kryteriów poprzedniej grupy. Niemniej sam fakt powszechnego uznawania i używania poszczególnych ksiąg stawał się z czasem argumentem na tyle ważnym, by dla kolejnych pokoleń chrześcijan stać się rzeczywistym kryterium wyboru?. Jeszcze lepiej, gdy księgi uznawane były powszechnie w Kościołach starożytnych, najlepiej zaś apostolskich ${ }^{10}$. Wtedy argument ten nabierał szczególnego odcienia bezpośredniej zależności apostolskiej, o którym mowa była powyżej.

Innym „kryterium kościelnym” okazało się na przykład użycie liturgiczne pism, a nawet cytowanie danej księgi przez osoby cieszące się poważaniem we wspólnocie wiary, jak ojcowie Kościoła. Najbardziej zaś wyrazistym z tej grupy kryteriów, a jednocześnie najbardziej wymiernym $\mathrm{w}$ procesie formowania się oficjalnego kanonu było formalne uznanie ze strony autorytetu wspólnoty (jednoosobowego lub kolegialnego).

Znaczenie „kryteriów kościelnych” na etapie formacji kanonu Pisma Świętego dowartościowuje zdecydowanie wspólnotę wiary. Widziana przez pryzmat tych kryteriów wspólnota zdaje się decydować o doborze poszczególnych ksiąg, ich układzie w kanonie i sposobie ich rozumienia. Innymi słowy, wspólnota zadaje się decydować o kształcie Biblii.

Uważniejsza refleksja nad historią formacji kanonu sprzyja jednakże ostrożności w tak zdecydowanym dowartościowaniu roli wspólnoty.Już sam fakt chętniejszego używania w tej dyskusji określenia „uznania” i „rozpoznania”, a nie prostego „decydowania” sugeruje specyfikę dłu-

${ }^{9}$ Por. Augustyn, De doctrina christiana, II, 25.

${ }^{10}$ Por. Euzebiusz, Historia ecclesiastica, III, 3, 1; III, 24, 17. 
giego procesu formacji kanonicznej. Słowo „rozpoznanie” zdradza chęć poszukiwania tego, co autorytatywne, a nie jego formowanie. Kościół pierwszych wieków miał świadomość objawienia już otrzymanego, reguły wiary przechowywanej na przyszłe pokolenia. Chodzi tu również o stałą wolę tegoż Kościoła poszukiwania tego, co autentyczne, apostolskie. Bez uwzględnienia chęci zachowania łączności z tym objawieniem (kojarzonym z okresem apostolskim) oraz woli wyraźnego podporządkowania się jego autorytetowi trudno zrozumieć wewnętrzną logikę procesu formowania się chrześcijańskiej Biblii. Wystarczy choćby przypomnieć fundamentalną dla całego procesu konfrontację poszczególnych pism z tradycyjną regułą wiary.

Do zauważenia woli starożytnego Kościoła, by raczej „rozpoznawać” aniżeli „definiować”, zachęca i to, że Kościół ten „rozpoznawał” w oparciu o konkretne cechy danych pism. Cechy zaś te, których dotyczą „kryteria zewnętrzne” wyżej wspomniane, odnosiły się bezpośrednio do owego fundamentalnego okresu objawienia, któremu Kościół chciał być wierny: starożytność, apostolskość, ortodoksja itd.

Na koniec nie należy również pomijać obecności zauważanego przez ojców „kryterium duchowego”. Polegało ono na wewnętrznym doświadczeniu mocy i świadectwa Ducha Świętego w Piśmie Świętym. Opierało się więc ono na doświadczeniu duchowym w kontakcie z Pismem. I choć z natury swojej trudno było poddać je obiektywnej weryfikacji, jego obecność w pismach ojców Kościoła i pisarzy starożytności chrześcijańskiej potwierdza oddziaływanie, jakie było udziałem Pisma wobec wspólnoty.

Podsumowując, dojść możemy do podobnych jak w punkcie poprzednim wniosków. Na etapie formowania się danych pism w zbiory, a następnie w pełny kanon, dialog pomiędzy Pismem Świętym a wspólnotą wiary jest kontynuowany. Jest to dialog, w którym rozwija się wzajemne oddziaływanie. Z jednej strony Pismo Święte odnajduje szybko swoją nadrzędną i wyjątkową funkcję we wspólnocie, z drugiej strony to dzięki wspólnocie jest ono sformowane i określone.

\section{Biblia w procesie aktualizacji}

Tak jak na każdym z poprzednich etapów historii Kościoła, tak i obecnie żywotną kwestią dla każdego chrześcijanina pozostaje pro- 
blem aktualizacji Pisma Świętego we współczesności. Człowiek wiary chce słuchać słowa Bożego, rozumieć je w sposób zgodny z intencją jego Autora i dostosowywać do niego swoje życie, ufając, że doprowadzi go ono do zbawienia. Jako że chrześcijanin słucha słowa Bożego w Kościele, i na tym etapie historii zbawienia istotną pozostaje kwestia odniesienia autorytetu wspólnoty wiary do autorytetu Pisma Świętego.

Fundamentalny dla współczesnej katolickiej interpretacji biblijnej dokument Kościoła Konstytucja dogmatyczna o Objawieniu Bożym Dei Verbum została po Soborze Watykańskim II powszechnie odczytana jako zachęta do ustawienia Biblii w centrum refleksji teologicznej Kościoła. Faktycznie w 24 punkcie tejże konstytucji czytamy znamienne słowa:

Święta teologia opiera się na spisanym słowie Bożym w łączności ze świętą Tradycją jakby na trwałym fundamencie. W nim coraz bardziej się ugruntowuje i nieustannie odmładza, zgłębiając w świetle wiary całą prawdę zawartą w tajemnicy Chrystusa. Święte Pisma zawierają bowiem słowo Boga, a jako natchnione rzeczywiście są słowem Boga. Z tego powodu niech studium ksiąg świętych stanie się niejako duszą świętej teologii. Tym samym słowem Pisma skutecznie żywi się oraz święcie umacnia także posługa słowa, to jest kaznodziejstwo, nadto katecheza i wszelkie nauczanie chrześcijańskie... ${ }^{11}$

Nie ma więc wątpliwości, Pismo Święte zostaje tu wyraziście rozpoznane jako najwyższy autorytet w Kościele.

Jednakże w samym tym sztandarowym dla ukazania wyjątkowego miejsca Pisma Świętego w Kościele punkcie konstytucji odnajdziemy sygnał napięcia znanego nam już z poszczególnych etapów formacji Biblii, a dotyczącego roli wspólnoty. Dokument soboru mówi o „słowie Bożym w łączności ze świętą Tradycją". W punkcie 12 konstytucji podkreśla się natomiast, że do prawidłowej lektury Biblii potrzebna jest uwaga na „żywą Tradycję całego Kościoła oraz analogię wiary”. Wszystko zaś to, co „dotyczy wyjaśniania Pisma, podlega ostatecznie osądowi Kościoła, który od Boga otrzymał nakaz i posługę strzeżenia i objaśniania Bożego słowa". Autorytet Biblii nie jest więc absolutny, musi odnaleźć się w relacji do autorytetu Kościoła. Relacja wzajemnego oddziaływania Pismo-wspólnota wiary znana z historii formacji biblijnej zachowuje swoją wartość.

${ }^{11}$ Sobór Watykański II, konst. Dei Verbum, § 24. 
Jak rozumieć tę relację w kontekście współczesnego poszukiwania pewnego i najwyższego autorytetu dla chrześcijanina, tak by nie narażać się na wewnętrzną sprzeczność i niespójność wykładu? Odpowiedź musi potwierdzać zgodnie ze współczesną wykładnią Soboru Watykańskiego II nadrzędną rolę słowa Bożego. Z drugiej strony nie może też pomniejszać autorytetu Kościoła Chrystusowego. Rozwiązanie typowe dla protestanckiego interpretatora, w którym autorytet Kościoła ogranicza się zasadniczo jedynie do uznania w sobie wiernego odbiorcy słowa Bożego zawartego w Biblii - nawet jeśli teologicznie wnikliwie dopracowane ${ }^{12}$ - z oczywistych względów eklezjologicznych nie może być dla strony katolickiej wystarczające.

Bardziej pomocna wydaje się tu być propozycja Karla Rahnera. Ten niemiecki teolog patrzy na Pismo jako będące nie tylko w szczególnej relacji do Kościoła, ale przede wszystkim jako zajmujące szczególne miejsce w samym sercu Kościoła. Kościół i Pismo rodziły się w tym samym tempie i czasie, wzajemnie się określając. Co więcej, zdaniem Rahnera ani Kościół, ani Biblia nie były w pełni kompletne i przygotowane do podróży poprzez wieki aż do momentu, w którym odnalazły wzajemną relację. Relacja ta wypełnia się zaś we wzajemnym pełnieniu roli normy hermeneutycznej: Biblii wobec Kościoła oraz Tradycji Kościoła wobec Biblii. W takim przedstawieniu Biblia jest istotną częścią Kościoła niesioną w Tradycji tegoż Kościoła przez wieki, ale jednocześnie częścią na tyle wyjątkową, by móc pełnić wobec wspólnoty ludu Bożego rolę normy krytycznej. Prawdziwy Kościół w każdym momencie swej historii odnajduje w Piśmie Świętym swoje prawdziwe oblicze ${ }^{13}$.

${ }^{12}$ Dobry przykład takiej propozycji prezentuje J. Webster. W decydującej części swego wykładu wyraża się znacząco: „autorytet Kościoła nie jest żadnym innym niż ten związany z uznaniem normy, której jest on podległy” - ,authority of the church is nothing other than its acknowledgment of the norm under which it stands" (J. Webster, A Great and Meritorious Act of the Church? The Dogmatic Location of the Canon, [w:] Die Einheit der Schrift..., dz. cyt., s. 121). W takim ustawieniu problemu, akcent przesuwa się zdecydowanie na stronę Biblii, pozostawiając Kościół w sferze pasywnej recepcji.

${ }^{13}$ Por. K. Rahner, The Foundations of Christian Faith. An Introduction to the Idea of Christianity, New York 1978, s. 370-373; J. T. Lienhard, The Biblie, the Church, and Authority, Collegeville 1995, s. 93-95. 
Jaki stąd wniosek? Wydaje się, że podstawowy jest ten, który nasuwał się już podczas refleksji na temat historii formacji kanonicznej. Ważne jest Pismo Święte, ważny jest Kościół, którego istotną częścią jest samo Pismo, ale ważny jest również trzeci trudniejszy do określenia element: odpowiednia relacja jednego do drugiego. Relacja ta zachowuje nieustannie swą wartość, bo Pismo jest konstytucją wspólnoty, współtworzy ją i dopełnia. Wspólnota i Pismo dopełniały się na przestrzeni wieków w procesie formowania się samych pism, a później ich kanonu. Owo szczególne „dopełnianie się" miało miejsce także później, gdy akcent położony został na interpretację tekstów, z „dopełniającą” hermeneutyczną rolą reguły wiary zanurzonej w Tradycji wspólnoty. I o to samo chodzić pewnie powinno w prawidłowym procesie współczesnej aktualizacji. Kościół wraz ze swym magisterium nie może wynosić się ponad autorytet słowa Bożego, a jednocześnie słowo to nie może wiernie wybrzmieć bez środowiska, którego jest nierozerwalną częścią - Kościoła. Historia formacji kanonicznej uczy nas, że właśnie w podtrzymywaniu tego twórczego "napięcia”, a nie w jego niwelowaniu poszczególne pokolenia wierzących odnajdywać mogą właściwe kierunki interpretacji i aktualizacji słowa Bożego. Prawdziwego źródła bowiem tego "napięcia” szukać możemy w Tym, który był zarówno u początków, jak i w trakcie powstawania Biblii i Kościoła, i którego żywa obecność jest obiecana także Kościołowi naszych czasów.

Kraków

ARTUR SANECKI SCJ

\section{Słowa kluczowe}

Kanon biblijny, krytyka kanoniczna, kryteria kanoniczności, tradycja, wspólnota wiary

\section{Summary}

"The Book of the community" or "the community of the

Book"? Location problem of theological authority

The article concerns the relationship between the Holy Scripture and the community of faith. The interaction of the community on the Scripture and that of the Scripture on the community are analyzed. First the elements of interaction during the period of formation of various scriptures are described. Already then we can talk 
about a kind of theological and existential dialogue between Scripture and community. Thanks to this dialogue both the community and the Scripture can develop. The same dialogue continues in the second period too, when the biblical canon is formed. At this stage a special role play so called 'criteria of canonicity', which operate within the community. Finally, we can recognize the contemporary modality of this never-ending dialogue in the process of actualization of Bible in the Church. What can be helpful in this contemporary process of actualization is the hermeneutical attitude identified in the previous stages of that dialogue.

\section{Keywords}

Biblical canon, canonical criticism, criteria of canonicity, tradition, community of faith 
Wyższe Seminarium Duchowne Towarzystwa Salezjańskiego w Lądzie zaprasza na

\section{LĄDZKIE SYMPOZJUM LITURGICZNE}

na temat Celebracja chrztu świętego a współczesne wyzwania

pod patronatem ks. dra Marka Chmielewskiego SDB - inspektora, Towarzystwa Naukowego Franciszka Salezego

\section{PIĄTEK 19 października 2012}

Sesja I

$9^{00}$ Otwarcie sympozjum - ks. dr Ryszard Sadowski SDB, rektor WSDTS w Lądzie

$9^{05}$ Słowowstępne-ks. dr RadosławBłaszczyk SDB, wychowawcai wykładowca liturgiki w WSDTS w Lądzie

$9^{15}$ Wspomnienie ośp. ks.prof. drhab. Adamie Duraku SDB (1949-2005) - ks. dr Ryszard Sadowski SDB

$9^{30}$ Lądzkie Sympozja Liturgiczne (1986-2009) - charakterystyka - ks. dr Radosław Błaszczyk SDB

$9^{45}$ Chrzest sakramentem wtajemniczenia a wychowanie do świadomości chrzcielnej - ks. prof. dr hab. Helmut Sobeczko, UO

$10^{15}$ Dyskusja

$10^{30}$ Przerwa na kawę

$11^{00}$ Katecheza przedchrzcielnaw rękach laikatu: ks. dr Szymon Stułkowski, UAM
$12^{00}$ Uroczysta eucharystia koncelebrowana w intencji śp. ks. prof. dra hab. Adama Duraka SDB pod przewodnictwem i z homilią bpa dra Stefana Cichego, członka Komisji ds. Kultu Bożego i Dyscypliny Sakramentów Konferencji Episkopatu Polski

$13^{15}$ Obiad

\section{Sesja II}

$14^{30}$ Nowa redakcja (ttumaczeń) ksiag liturgicznych - aktualne prace Komisji ds. Kultu Bożego i Dyscypliny Sakramentów Konferencji Episkopatu Polski - bp dr Stefan Cichy

$15^{00}$ Miejsce symboliki chrzcielnej w mistagogi liturgicznej-ks. dr hab.Erwin Mateja, UO

$15^{30}$ Krakowskie doświadczenia katechumenalne -s. dr hab. Adelajda Sielepin CHR, UPJPII

$16^{00}$ Dyskusja

$16^{30}$ Podsumowanie obrad - ks. dr Radosław Błaszczyk SDB

Koszt uczestnictwa: $30 \mathrm{zł} \mathrm{(z} \mathrm{obiadem).}$

Nocleg: dworek około 300 m od seminarium w cenie 40 zł za dobę hotelową rozpoczynającą się o godz. $16^{00}$ i kończącą o godz. 1200, rezerwacja: tel. (602) 6632 34, (63) 27633 07, e-mail: poczta@dworlad.pl.

Zgłoszenia do 30 IX 2012, tel. (785) 4804 76, e-mail: radekb@tlen.pl. 